\title{
Expression, Microencapsulation of Recombinant Human Epidermal Growth Factor, and Release Study in Gastric Ulcer Representing Condition
}

\author{
Riyona Desvy Pratiwi ${ }^{*}$, Nurfina Yudasari², Viddy Agustian Rosyidi ${ }^{3}$ Sabighoh Zanjabila1,

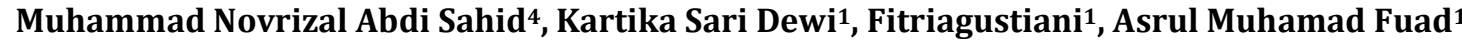

1. Research Center for Biotechnology, Research Organization for Life Sciences, National Research and Innovation Agency (BRIN), Jalan Raya Bogor Km. 46, Bogor, West Java 16911, Indonesia

2. Faculty of Pharmacy, University of Jember, Krajan Timur, Sumbersari, Jember, East Java 68121 Indonesia

3. Research Center for Physics, Research Organization for Engineering Sciences, National Research and Innovation Agency (BRIN), Kawasan Puspitek Serpong, Tangerang Selatan, Banten 15314, West Java, Indonesia

4. Faculty of Pharmacy, Universitas Gadjah Mada, Jalan Sekip Utara, Sleman 55281, The Special Region of Yogyakarta, Indonesia

\begin{tabular}{|c|c|}
\hline Info Article & ABSTRACT \\
\hline Submitted: $10-05-2021$ & Recombinant human epidermal growth factor (rhEGF) has been \\
\hline Revised: 08-12-2021 & studied and expressed in various expression systems. It has been also \\
\hline Accepted: $18-12-2021$ & commercialized and clinically used, yet limited to topical diseases. However, \\
\hline $\begin{array}{l}\text { *Corresponding author } \\
\text { Riyona Desvy Pratiwi }\end{array}$ & $\begin{array}{l}\text { being naturally expressed in different tissues, the rhEGF is potential to be } \\
\text { applied not only for external wound and skin disorders, but also to } \\
\text { regenerates internal damaged epidermal cells such found in gastric ulcer. In }\end{array}$ \\
\hline $\begin{array}{l}\text { Email: } \\
\text { riyona.desvy.pratiwi@lipi.g } \\
\text { o.id; }\end{array}$ & $\begin{array}{l}\text { the recent study, chitosan microparticles were developed to facilitate delivery } \\
\text { of the rhEGF and to overcome gastric degradation that majorly interfere } \\
\text { protein, particularly rhEGF oral administration. The rhEGF was expressed in }\end{array}$ \\
\hline riyona.desvy.pratiwi@brin. & E. coli BL21(DE3) and purified using Ni-NTA chromatography. The refolded \\
\hline 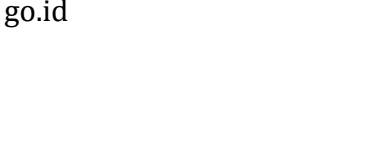 & $\begin{array}{l}\text { rhEGF showed proliferation activity on MCF7 cells. rhEGF loaded chitosan } \\
\text { microparticles were stable in the gastric and specifically released the loaded } \\
\text { rhEGF in the high oxidative environment in acidic pH representing gastric } \\
\text { ulcer condition. }\end{array}$ \\
\hline & $\begin{array}{l}\text { Key words: epidermal growth factor, chitosan microparticle, gastric ulcer, } \\
\text { targeted release }\end{array}$ \\
\hline
\end{tabular}

\section{INTRODUCTION}

Gastric ulcer is a manifestation in health condition caused by infection of Helicobacter pylori, non-steroidal anti-inflammatory drugs (NSAIDs), and hypoxia or stress condition in the gastric (Huang et al, 2002; Bhattacharyya, et al, 2014). The ulcer is formed by margin layer containing nonnecrotizing mucosa such as epithelial cells, and base layer consisting of granulation tissue eg. fibroblast, macrophage, also endothelial cells (Syam, et al, 2009). Enhancing the proliferation of the epithelial cells on the margin layer is the priority strategy for the ulcer healing by reepithelization of the mucosa surface and reconstruction of the gastric gland (Tarnawaski, 2000).

Epidermal growth factor (EGF) is the most important cytokines in healing mechanism in gastric ulcer that induces proliferation and maturation of epithelial cells (Goodsell, 2003; Bodnar, 2011). However, at severe stage of the gastric ulcer, EGF which is naturally secreted in the body is inadequate to induce proliferation and maturation of the epithelial cells due to degradation by proteases from $H$. pylori and competition with these bacteria to bind to EGFR (Posselt, et al, 2017). Therefore, exogenous EGF is requested in the severe gastric ulcer therapy.

The exogenous EGF is provided by protein engineering to produce the recombinant protein using an appropriate expression system. E. coli is the most favorable expression system used to produce recombinant protein. In the previous study, we constructed our synthetic gene of hEGF with plasmid pET21b(+) and then transformed it into E. coli $\mathrm{DH} 5 \alpha$ subcloning host (Nurmalasari, 
2010). In this study, the recombinant plasmid pET21b(+)_hEGF_6 $\times$ His-tag was expressed in $E$. coli BL21(DE3).

The rhEGF was then formulated into microparticles to ensure its delivery to the damaged gastric. We intended to apply chitosan microparticles for the rhEGF oral delivery because the materials used are available in the nature and safe. In addition, the preparation is simple, organic solvent free, and applicable for large production.

The delivery system is designed to adsorb the rhEGF in a physiological environment, including in neutral and acid conditions and then it has the ability to release the rhEGF in damaged tissue in the gastric ulcer. In patients with gastric ulcer, their gastrointestinal $\mathrm{pH}$ is around $2.4 \pm 1.9$ (as comparison, gastric $\mathrm{pH}$ in healthy subject is 1.7 \pm 0.2 ) (Machida, 1981). Moreover, the damaged condition has higher oxidative stress compared to healthy tissue (Suzuki, et al, 2012). This condition is used to trigger the rhEGF release from the microparticles.

The rhEGF has been encapsulated in several microcarrier systems for local or dermal administration (Sriwidodo, et al, 2020; Zhang, et al, 2020). Therefore, this is the first study of encapsulation of the rhEGF which is purposed for nondermal application, particularly for gastric ulcer. This study was aimed to produce purified and active rhEGF and then prepare a suitable formulation for oral delivery of the rhEGF, specifically for gastric ulcer therapy.

\section{MATERIALS AND METHODS}

Expression, purification, and characterization of recombinant human epidermal growth factor The recombinant plasmid pET21b(+)_rhEGF_6 6 His-tag obtained from the previous study was isolated from its subcloning host E. coli DH5 $\alpha$ using alkaline lysis method and transformed into an expression host E. coli BL21(DE3) by heat-shock method (Ausuble, et al, 1999). The rhEGF was expressed in Luria Bertani media by IPTG induction which was optimized at concentration $0.1 \mathrm{mM}$ and $4 \mathrm{~h}, 37^{\circ} \mathrm{C}$ incubation. The cells pellet was harvested by centrifugation at $6.000 \mathrm{rpm} ; 15 \mathrm{~min} ; 4^{\circ} \mathrm{C}$ and solubilized with solubilization buffer ( $8 \mathrm{M}$ urea, $80 \mu \mathrm{M} \beta$-mercaptoethanol, $30 \mathrm{mM}$ glycine; $60 \mathrm{~mL}$ solubilization buffer for pellet from $300 \mathrm{~mL}$ cells culture) incubated at $4^{\circ} \mathrm{C}$ for $24-48 \mathrm{~h}$ ). Solubilized protein was separated with the pellet residue by centrifugation 12,000 $\mathrm{rpm}, 4^{\circ} \mathrm{C}, 20 \mathrm{~min}$.
The solubilized protein was then mixed with slurry of Ni-NTA agarose enriched with equilibrium buffer $(0.05 \%$ Tween $20,30 \mathrm{mM}$ imidazole in phosphate saline buffer) and incubated at $4{ }^{\circ} \mathrm{C}$ for $18 \mathrm{~h}$. Contaminant proteins were removed in washing steps using washing buffer $(50 \mathrm{mM}$ in phosphate saline buffer). Subsequently, target protein (rhEGF_6×HisTag) was eluted with elution buffer $(100 \mathrm{mM}$ imidazole in phosphate saline buffer). The purified rhEGF_6×HisTag was refolded by two methods of dialysis against stepwise concentrations of arginine (0-0.05 $\mathrm{M}$ arginine and 0.5-0 M urea) and one concentration of GSH $(0.03$ $\mathrm{M}$ GSH and 0.5-0 M urea). Refolding was performed at $8-10^{\circ} \mathrm{C}, 6 \mathrm{~h}$ for each step with urea and overnight for the last dialysis without urea. Except, the first step with GSH and urea was performed in room temperature for $3 \mathrm{~h}$.

The refolded rhEGF_6 6 HisTag was concentrated by filtration using $10 \mathrm{kDa}$ membrane filter with low speed centrifugration $(8,000 \mathrm{rpm}$; $5 \mathrm{~min} ; \quad 10^{\circ} \mathrm{C}$ ). Tricine-SDS PAGE with $15 \%$ acrylamide was used for analyzing protein profile. For protein quantification, image of tricine-SDS PAGE was converted into green colored band with black background for a better contrast with Image Studio Digit $\AA$ and then the specific bands were measured using Image $\mathrm{B}$. Western blot was done by using anti-rhEGF antibody. The rhEGF stability in acidic solution was performed by incubating the refolded rhEGF in $\mathrm{HCl} 0.1 \mathrm{~N}$ at $37^{\circ} \mathrm{C}$ for 0,1 , and 2 $h$, respectively. After incubation the protein was analyzed with tricine-SDS PAGE. Concentration ratio of the incubated and not incubated protein was semi-quantified using ImageJ software (Arya, et al, 2015).

\section{In vitro bioassay of rh-EGF proliferation activity on MCF7 cell line}

MCF7 cell line (confluency 80-90\%) was trypsinized and resuspended in serum free DMEM (1.105 cells $/ \mathrm{mL}$ ). The cell suspension $(100 \mu \mathrm{L} /$ well) was incubated in 96 well plate, $24 \mathrm{~h}$, $37{ }^{\circ} \mathrm{C}, 5 \% \mathrm{CO}_{2}$. On the next day, the media was discharged and refreshed with new media supplemented with rhEGF. The cells were incubated with the rhEGF for $24 \mathrm{~h}$, followed by MTT addition $(20 \mu \mathrm{L} /$ well $)$. The cells were then incubated with MTT for $4 \mathrm{~h}$. The media was recharged with DMSO supplemented media. Prior to read absorbance at $570 \mathrm{~nm}$, the cells were incubated with DMSO for $20 \mathrm{~min}$ at room temperature. 
Formula optimization for chitosan microparticles with BSA as model protein and preparation of rh-EGF loaded microparticles. Bovine serum albumin (BSA) was used as protein model in formula optimization. BSA and chitosan were dissolved in $0.1 \mathrm{~N}$ acetic acid $\mathrm{pH} 5$, respectively. STPP/carrageenan were dissolved in water for injection. Chitosan and STPP were prepared in various concentration (Table. I). BSA, and chitosan, and STPP/carrageenan solutions (ratio 1:1:1) were mixed with vortex (Thermo Scientific) at maximum speed, approximately 3,200 rpm. First, BSA and chitosan solutions were mixed for $60 \mathrm{~s}$, then added with STPP/carrageenan solution and mixed for $60 \mathrm{~s}$ as well.

One optimized formula was used to entrap the rhEGF. The refolded rhEGF was concentrated using membrane filter $10 \mathrm{kDa}$ by centrifugation at low speed, 6,000 rpm, $5 \mathrm{~min}, 4{ }^{\circ} \mathrm{C}$. This concentrated rhEGF $(0.3 \mathrm{mg} / \mathrm{mL})$ was directly mixed with chitosan and STPP solution, without any solvent addition. Standard rhEGF was dissolved in water for injection before being mixed with chitosan and STPP.

\section{Entrapment efficiency measurement}

Entrapment efficient of the protein was calculated from the ratio of bound and unbound protein. The bound protein was separated from unbound protein by centrifugation at $12,000 \mathrm{rpm}$ for $15 \mathrm{~min}$. The unbound protein in optimization study was analyzed with Nanodrop ${ }^{\mathrm{TM}}$ spectrophotometer and confirmed with SDS PAGE, but unbound protein in rhEGF loaded microparticles was analyzed by bicinchoninic acid (BCA) assay, for more sensitive detection.

$\% \mathrm{LE}=\frac{\mathrm{A}}{\mathrm{B}} \times 100 \%$

$\% \mathrm{LC}=\frac{\mathrm{A}}{\mathrm{B}+\mathrm{C}} \quad \times 100 \%$

$\mathrm{A}=$ Unbound protein (mg); $\mathrm{B}=$ Bound protein (mg); $\mathrm{C}=$ empty chitosan microparticle.

\section{Physical characterization of chitosan} microparticles

Hydrodynamic size was measured using Zetasizer Micro Range, Malvern Analytical. Morphology of microparticle was observed under scanning electron microscope JSM IT200, JEOL, Japan.
In vitro release study of rh-EGF loaded microparticles in condition representing gastric ulcer

Dispersion of rhEGF loaded microparticles (1 $\mathrm{mL}$ in each microtube) was centrifugated at $12,000 \mathrm{rpm}$; $15 \mathrm{~min}$ to obtain pellet of rhEGF loaded microparticles. The pellet was then added with $\mathrm{HCl} 0.1 \mathrm{~N}, \mathrm{pH} 1$ and incubated at $37{ }^{\circ} \mathrm{C}$. Samples were collected at $0 ; 5 ; 10 ; 15 ; 30 ; 60$; and 120 min after being incubated in $\mathrm{HCl} 0.1 \mathrm{~N} \mathrm{pH} 1$ by centrifugation at $12,000 \mathrm{rpm}$; $15 \mathrm{~min}$. Other pellets from samples which had been incubated in $\mathrm{HCl} 0,1$ $\mathrm{N} \mathrm{pH} 1 ; 37{ }^{\circ} \mathrm{C} ; 2 \mathrm{~h}$ were added with $\mathrm{HCl} 0.1 \mathrm{~N} \mathrm{pH} 1$ supplemented with GSH $10 \mathrm{mM}$ and incubated again at $37{ }^{\circ} \mathrm{C}$. The GSH incubated pellets were collected at $0 ; 15 ; 30$; and 60 min by centrifugation at 12,000 rpm; $15 \mathrm{~min}$. Supernatants obtained after centrifugation were analyzed with BCA assay. All samples were performed in duplicates

\section{RESULT AND DISCUSSION}

Expression, purification, characterization, and activity study of recombinant human epidermal growth factor

The rhEGF has been successfully expressed in E. coli BL21(DE3) under T7 promoter which was induced with IPTG. The protein was obtained as inclusion bodies, thus a solubilization process is required. Figure 1(a) lane 2 shows solubilized rhEGF before purification. A thick band was observed at approximately $6.5 \mathrm{kDa}$.

In order to remove contaminants or endogenous proteins, purification using Ni-NTA matrix was performed. The rhEGF was designed with $6 \times$ Histag fusion at C-terminal. Therefore, the $6 \times$ Histag was bound to nickel on the matrix. Proteins without any multiple histidine could not bind to the matrix and collected in the flow through fraction. Figure 1(a) lane 3 depicts that no rhGEF was released in the flow through which means that the protein target entrapment was sufficient. Contaminant proteins containing multiple histidine were also found in the first elution fraction (Figure 1(a) lane 7). However, in the next elution fractions, a single band of purified rhEGF was obtained. All elution fractions, except the first elution were collected and then refolded with arginine.

Prior to confirm whether the refolded rhEGF has bioactivity, the purified protein was characterized using western blot against antirhEGF monoclonal antibody. Positive blotted bands were characterized (Figure 1(b)). 
Activity of the refolded rhEGF to induce cell proliferation was tested on MCF7 cell line. In this study, the MCF7 cell line was selected for the bioactivity assay of the rhEGF because it showed a significant sensitivity and mitogenic response among other cancer cells lines tested in a previous study (Fitzpatrick, et al, 1984). The EGFR specifically responded to the EGF during the S/G2 phase of the cell cycle (Walker, et al, 2007).
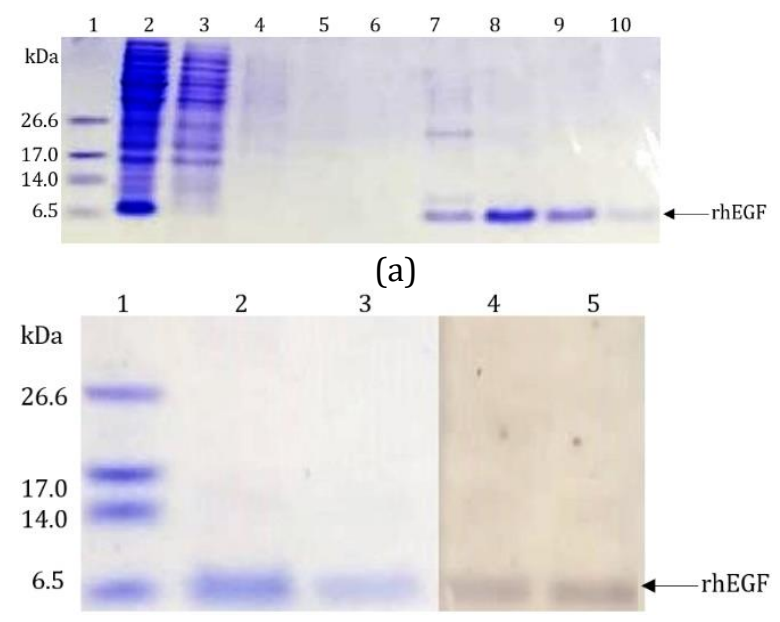

(b)

Figure 1. Expression, purification, and characterization of rhEGF. (a) The rhEGF profile before and after purification using Ni-NTA matrix. Lane 1: protein marker; lane 2: protein crude (before purification); lane 3: flow through fraction; lane 4 - 6: washing fractions; lane 7 - 10: elution fractions. (b) The rhEGF blotting profile against anti-rhEGF monoclonal antibody. Lane 1: protein marker; lane 2-3: purified rhEGF on SDS PAGE gel; lane 4-5: blotted rhEGF on nitrocellulose membrane.

Regarding to the bioassay for the refolded rhEGF, the MCF7 cell line was considered as an appropriate and sensitive method.

The MCF7 cell line was treated with rhEGF and incubated for $24 \mathrm{~h}$. Significant activity towards negative control or untreated cells was found in rhEGF $30 \mathrm{ng} / \mathrm{mL}$. This is the optimized concentration of the rhEGF to induce the MCF7 cell proliferation. The highest concentration of the rhEGF showed opposite result which caused cell death. Kim et al (2015) reported that at certain concentration, the rhEGF might shows paradox effect leading to cell death which is related to suppression of PI3K/AKT/mTOR signaling pathway. The MTT assay proved that the refolding process was appropriate (Figure 2).
Refolding of denaturated rhEGF is a complex process. This protein posseses three six cysteine residues which contributes to form three intrachain disulfide bonds. These disulfide bonds determine particular hEGF loops. Three loops of hEGF specifically interact with two among three domains of C-shaped hEGFR (Ogiso, et al, 2002). A molecule of hEGF binds with a molecule of hEGFR and triggers rhEGF dimerization by interaction with another complex of hEGF-hEGFR (Ogiso, et al, 2002). Once the hEGFR dimer is arranged, the following tyrosine kinase-related cascade is activated (Goodsell, 2003). Thus, inappropriate refolding or mismatched cysteine bounds generate no biological activity (Kozlova, et al, 2016). The refolded rhEGF was then encapsulated with chitosan after the optimized formula was obtained.

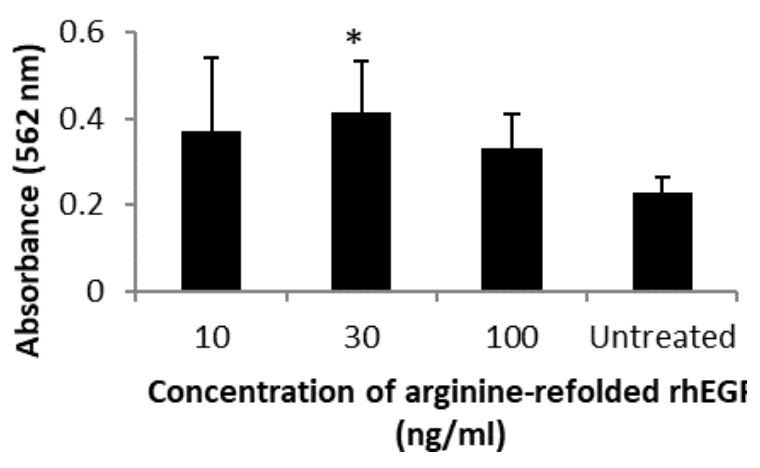

Figure 2. Bioactivity of arginine refolded-rhEGF to induce proliferation of MCF7 cell line detected with MTT assay

\section{Formula optimization for chitosan-based particles}

Formula optimization was carried out using a model protein, bovine serum albumin (BSA). The model protein was used instead of the rhEGF in the optimization step by considering the economic value and difficulty level of producing the purified protein. In addition, BSA was chosen because of similarity of substantial physical characterization with rhEGF, in terms of chitosan encapsulation. Protein $\mathrm{pI}$ is the most important parameter in the recent study in which protein loading was highly depended on ionic interaction of protein and chitosan, in other words it relies on protein pI and $\mathrm{pH}$ of chitosan solution. pI of BSA and EGF was quite similar, i.e 4.8 and 4.5, respectively (Zeng, et al, 1998; Deng, et al, 2006).

Combination formulas of chitosan and its crosslinker (STPP and carrageenan) are listed (Table I). Chitosan and carrageenan are natural polymers having opposite ionic charges in neutral 
pH. Combination of those polyelectrolytes physically forms an ionotropic hydrogel. Concentrations of polyelectrolytes determine structure of the hydrogel which are micro/nanoparticles or beads. This physical interaction is reversible and disrupted by changes of $\mathrm{pH}$, ionic strength, or temperature (Grenha, et al, 2009). Similar with carrageenan, STPP is also a compound having a negative charge, therefore can be used as a crosslinker for the chitosan-based particles (Yang, et al, 2009). Crosslinks between $\mathrm{NH}_{3}{ }^{+}$of chitosan and $\mathrm{P}_{3} \mathrm{O}_{5}^{-}$or $\mathrm{HP}_{3} \mathrm{O}_{4}^{-}$of STPP and $\mathrm{R}-\mathrm{SO}_{3}$ - of carrageenan are the main intra and intermolecular interaction to form the particles (Triwulandari, et al, 2018).

Table I. Formula optimization of chitosan microparticles using bovine serum albumin as protein model

\begin{tabular}{cccc}
\hline Formula & $\begin{array}{c}\text { Chitosan } \\
\text { (\%) }\end{array}$ & $\begin{array}{c}\text { Carrageenan } \\
\text { (\%) }\end{array}$ & $\begin{array}{c}\text { STPP } \\
\text { (\%) }\end{array}$ \\
\hline A1 & 0.1 & - & 0.01 \\
A2 & 0.4 & - & 0.01 \\
A3 & 0.1 & - & 0.04 \\
A4 & 0.4 & - & 0.04 \\
B1 & 0.1 & 0.01 & - \\
B2 & 0.3 & 0.01 & - \\
B3 & 0.1 & 0.05 & - \\
B4 & 0.3 & 0.05 & - \\
\hline
\end{tabular}

Table II. Analysis of BSA loaded microparticles

\begin{tabular}{ccccc}
\hline Formula & $\begin{array}{c}\text { Particle size } \\
\text { (nm) }\end{array}$ & PDI & \% EE & \% LC \\
\hline A1 & $400.7 ; 0.271$ & 0.271 & 71.24 & 8.85 \\
A2 & $308.3 ; 0.225$ & 0.225 & 65.77 & 2.35 \\
A3 & $426.8 ; 0.290$ & 0.290 & 58.66 & 5.91 \\
A4 & $516.6 ; 0.312$ & 0.312 & 59.76 & 1.99 \\
B1 & $514.4 ; 0.295$ & 0.295 & 77.24 & 9.50 \\
B2 & $860.7 ; 0.484$ & 0.484 & 67.39 & 3.15 \\
B3 & $1196.0 ; 0.524$ & 0.524 & 59.76 & 5.63 \\
B4 & $732.1 ; 0.380$ & 0.380 & 63.01 & 2.62 \\
\hline
\end{tabular}

The particle characterization in formula optimization study including particle size, polydispersity index (PDI), loading efficiency (LE), and loading capacity (LC) (Table II). In general, STPP crosslinked-chitosan microparticles were smaller in size and in PDI compared with the particles crosslinked with carrageenan. Chitosan based particles produce the smallest size using STPP as crosslinker, followed by carrageenan, alginate, and sodium dodecyl sulphate (Wulandari, et al, 2018). Formula A2 which resulting in the best PDI and the smallest size was then chosen to encapsulate the rhEGF.

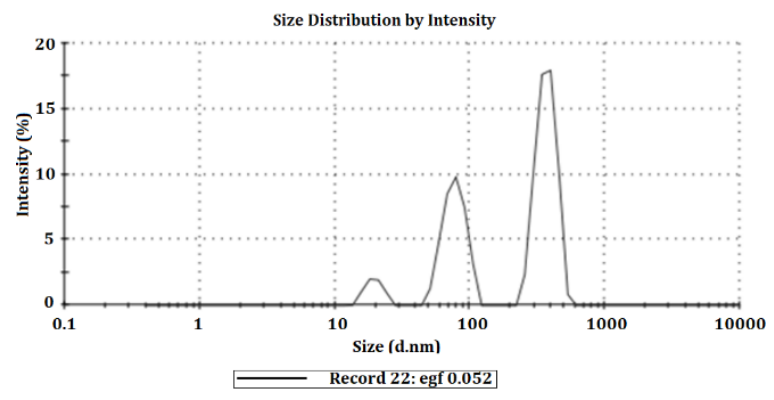

Figure 3. Size distribution by intensity of rhEGF loaded chitosan microparticles

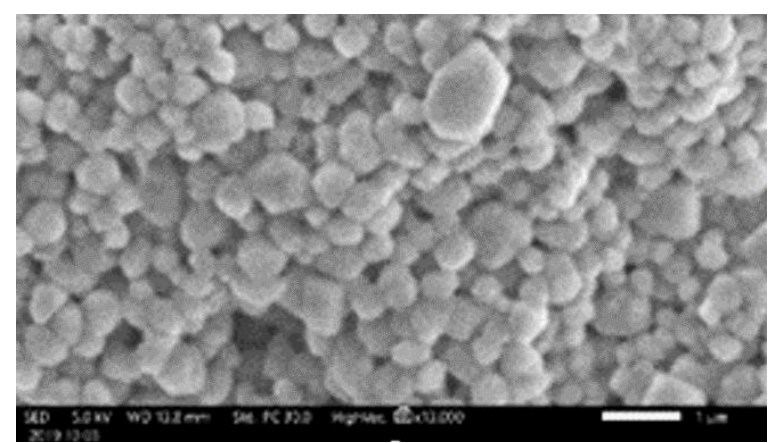

Figure 4. Morphology of rhEGF loaded chitosan microparticles $(\times 13,000)$

\section{rh-EGF loaded chitosan microparticles, in vitro release study and physical characterizations thereof}

Using the exact formula with BSA (Formula A2), rhEGF loaded chitosan microparticles have approximately twice bigger in size, which is $617 \mathrm{~nm}$ in average with PDI 0.619 compared than that of BSA loaded chitosan microparticles (Figure 3 and Figure 4). This result proves that protein molecular weight does not linearly correlate with final hydrodynamic size of a protein loaded particles. Hydrodynamic size or dimension of a protein not only depends on the molecular weight, but also its tertiary structure which is affected by a number of parameters such as folding/unfolding states and environmental $\mathrm{pH}$. Hydrodynamic size/dimension also reflects oligomer or aggregate of protein (Zheng, et al, 2016). In hydrodynamic size, BSA and EGF are almost similar. BSA is reported having 3.3 $-4 \mathrm{~nm}$ or $3.7 \mathrm{~nm}$ hydrodynamic size and so is EGF (3.7 nm) (Jachimska, et al, 2008; Thone et al, 2004; 
Brownsey, et al, 2003). In addition, unfolded state of rhEGF is also potential to contribute to the bigger rhEGF-loaded chitosan microparticles (Zheng, et al, 2016).

In order to assess capability of the chitosan microparticles to entrap the rhEGF in gastric ulcer representing environment, a release in vitro study was performed. The system mimicked $\mathrm{pH}$ and temperature of the gastric condition, i.e pH 1.237 ${ }^{\circ} \mathrm{C}$ and incubated for $2 \mathrm{~h}$ - minimal time needed for gastric digestion (Hoebler, et al, 2002). This is an extremely destructive environment that must be passed by the protein delivery system.

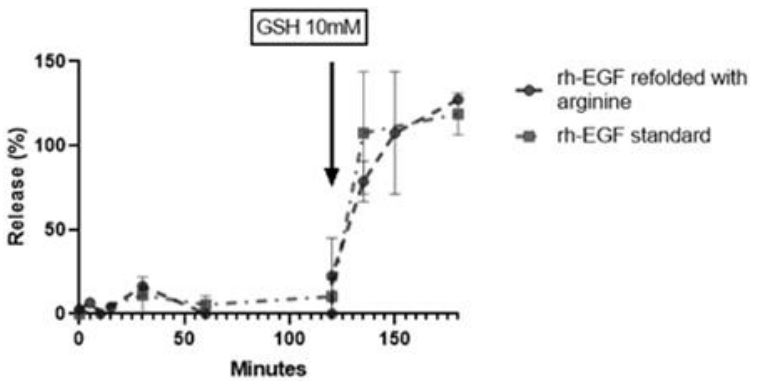

Figure 5. rhEGF release profile in gastric ulcer representing environment LE standard: 59.03\%; LC standard: 5.3\%, EE rhEGF: 51.33\%, LC rhEGF: $7.15 \%$

Release profile of the arginine folded rhEGF and rhEGF standard loaded chitosan microparticles was compared (Figure 5). Both of delivery system show alike release profile. Corresponding to stability, the chitosan microparticles exhibit capability to entrap the rhEGF in the extremely low $\mathrm{pH}$ of gastric environment in which approximately less than $20 \%$ of rhEGF was released (Figure 5) (Raza, et al, 2020).

Gastric ulcer is characterized with elevated level of oxidative stress which closely related to numerous gastric diseases such as $H$. pilori infection, ischemic injury, and lifestyle-related gastric diseases, for instance hypertension gastropathy and diabetes (Suzuki, et al, 2012). Therefore, the in vitro release testing system was added with GSH $10 \mathrm{mM}$ to trigger the rhEGF release from chitosan microparticles as one of typical indicators for gastric ulcer (Bhattamisra, et al, 2019). Started in $30 \mathrm{~min}$ after incubated with GSH, the rhEGF was completely released (Figure 5).

EGF is known stable in gastric fluid containing pepsin and gastric acid (Britton, et al, 1987). In our study, the refolded rhEGF was incubated in $\mathrm{HCl} 0.1 \mathrm{~N}$ at $37^{\circ} \mathrm{C}$, for 0,1 , and up to 2 $\mathrm{h}$ representing gastric transit condition. No other bands were found except a band of the rhEGF meaning that no major degradation caused by the related condition (Figure 6). Yet, comparing with the rhEGF without reaction with $\mathrm{HCl} 0.1 \mathrm{~N}$, the protein concentrations were slightly decreased which were 90.61; 91.26; and 90.60\%, respectively, quantified with Image software. Playford et al (1995) reported that in an in vivo study, four amino acids (AA 49 - 53) at C-terminal of the EGF was degraded in gastric acid and cleavage between Asp 46 and Leu 47 was found due to pepsin degradation. However, as previously mentioned, bioactivity of the EGF was strongly determined by the EGF loops formed by Cys 6 - Cys 20; Cys 14 Cys 31; and Cys 33 - Cys 42 (Ogiso, et al, 2002). In addition, the EGF preserves its bioactivity after gastric degradation up to $30 \%$ (Playford, 1995). Combination with omeprazole was recommended in order to obtain 3-4 times higher concentration of EGF in gastric fluid (Dutta, et al, 1987).

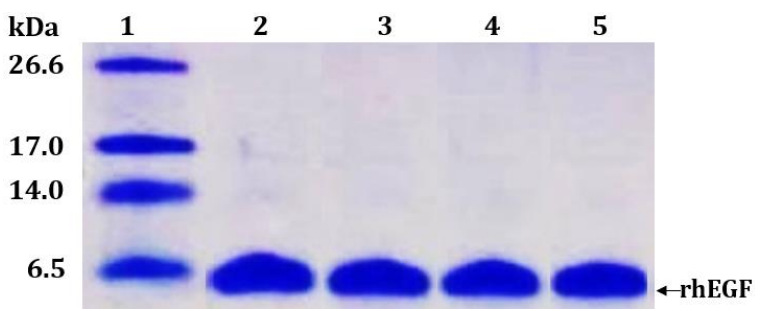

Figure 6. Stability of rhEGF in $\mathrm{HCl}$ at 37.5C. Lane 1: protein marker; lane 2: not incubated; lane 3: after $2 \mathrm{~h}$ incubation; lane 4: after $1 \mathrm{~h}$ incubation; lane 5: after $0 \mathrm{~h}$ incubation

Oral drug delivery is the most convenient and less invasive route administration. However, it is much challenging for macromolecule drugs, like protein because of gastric acidic condition and low permeability (Brown, et al, 2019).

Recombinant human epidermal growth factor (rhEGF) is one of top proteins used in therapies, but still limited in topical usages. Topical products containing rhEGF has been commercialized for diabetic foot, scald, and skin rejuvenation (Berlanga-Acosta, et al, 2017; Wong, et al, 2016; Aldag, et al, 2017). However, rhEGF is highly potential not only for topical cells renewal purposes, but also for damaged epithelial cells related-diseases, such gastric ulcer. In patient with gastric mucosal ulcer, the EGF level is lower than that of in patient with intact mucosa (Konturek, et $a l, 1997)$. 
Itoh and Matsuo (1994) reported that combination of intravenous rhEGF and cetraxate $\mathrm{HCl}$ showed a significant effect to heal gastric ulcer in rats. However, individual administration of those drugs was not effective. Therefore, it was suggested that an oral application of rhEGF prospectively would show more benefits (Itoh and Matsuo, 1994).

Chitosan has been studied in pharmaceutical formulation since early 1990s (Bernkop-Schnürch and Dünnhaupt, 2012). As development of microcarriers for proteins become interesting, chitosan is also considered as one of polymers to encapsulate protein, particularly for oral delivery (Bowmand and Leong, 2006).

Chitosan is soluble in acidic $\mathrm{pH}$, however in a large number of studies, drug-loaded chitosan microparticles did not show massive drug release in the gastric, yet floating and starting to perform drug controlled-release (Bowman and Leong, 2006; Pahwa et al, 2012). It is a mucoadhesive leading the chitosan-particles remain intact in the destructive gastric acidic environment. Moreover, chitosan is positively charged in acidic $\mathrm{pH}$, thus it binds well to cell membranes which increases permeability towards gastric membrane (Deacon, et al, 2000).

In the recent application, the chitosan microparticles were aimed to entrap and protect the rhEGF towards the destructive gastric environment, and by being sized in micro/micro, the chitosan particles easily enter the opened damaged tissue of the gastric ulcer and then released the rhEGF triggered by high oxidative level. The free radicals contribute to degrade the chitosan polymer and reduce its molecular weight, thus the capability of chitosan microparticles to encapsulate the rhEGF is obliterated leading to its release in the therapeutic target (Jennings, 2017).

An appropriate drug carrier could overcome unfeasibility and difficulty in delivering drugs, such as protein/rhEGF for oral administration. In addition, a specific triggered-release mechanism is beneficial in avoiding toxicity at non-therapeutic target and increasing the drug accumulation at therapeutic target which eventually escalate drug effectivity (Kundu, et al, 2019).

In order to prove the efficacy of the rhEGF microparticle, in vitro or cell study alone is inadequate because it requires a condition in which biological fluids changes are available and allows oxidation triggered-release of the rhEGF from the microparticle prior to targeting the ulcer in the gastric. An in vivo study using gastric ulcer - induced animal model is suggested for the further research.

\section{CONCLUSION}

Chitosan has been explored as a revolutionary delivery system for oral administration of rhEGF which is the most challenging route for protein. rhEGF has been expressed in E. coli BL21(DE3) using pET21 vector. In order to express the protein of interest, the expression system was induced with IPTG. The rhEGF was purified by Ni-NTA chromatography and then refolded with arginine. The refolded rhEGF showed a significant proliferation activity on MCF7 cells at $30 \mathrm{ng} / \mathrm{mL}$ compared with untreated cells. For oral delivery, the rhEGF was encapsulated with chitosan by adsorption mechanism forming microparticles. The chitosan microparticles successfully exhibited protection for rhEGF under extremely degradative gastric condition in an in vitro study and then specifically released the rhEGF in gastric ulcer representing environment.

\section{ACKNOWLEDGEMENT}

The authors would like to thank to Indonesia Toray Science Foundation for the financial support under ITSF Research Grant 2017 and Prof. Dr. apt. Edy Meiyanto for allowing us to use MCF7 cell line.

\section{REFERENCES}

Aldag C., Teixeira DN., Leventhal PS. (2016). Skin rejuvenation using sometic products containing growth factors, cytokines, and matrikines: A review of the literature. Clinical, Cosmetic, and Investigational Dermatology, 9:411-419. https://doi.org/10.2147/ccid.s116158.

Arya A., Gangwar A., Sharma NK., et al. (2015). Computational method for semiquantitative analysis of immunoblots of modified proteins using ImageJ. Journal of Protein and Proteomics, 6(3): 261-270

Ausubel FM., Brent R., Kingston RE., Moore DD., Seidman JG., Smith JA., Struhl K., Ferreira AJP., Neidhardt FC., Ingraham JL. \& Schaechter Mc. (1999). Short Protocols in Molecular Biology - A Compendium of Methods from Current Protocols in Molecular Biology. Wiley. New Jersey.

Berlanga-Acosta J., Fernandez-Montequin J., Valdes-Perez C., Savigne-Gutierrez W., Mendoza-Mari Y., Garcia-Ojalvo A, FalconCama V., del Barco-Herrera DG., FernandezMayola M., Perez-Saad H., Pimentel-Vazquez 
E., Urquiza-Rodiguez A., Kulikovsky M., Guillen-Nieto G. (2017). Diabetic foot ulcers and epidermal growth factor: revisiting the local delivery route for a succesful outcome. Biomed Research International, 292359. https://doi.org/10.1155/2017/2923759

Bernkop-Schnürch A., and Dünnhaupt S. (2012). Chitosan-based drug delivery systems. European Journal of Pharmaceutics and Biopharmaceutics, 81(3): 463-469. https://doi.org/10.1016/j.3jpb.2012.04.00 7

Bhattacharyya A., Chattopadhyay R., Mitra S., Crowe SE. (2014). Oxidative stress: An essential factor in the pathogenesis of gastrointestinal mucosal diseases, Physiological Review, 94(2):329-354.

Bhattamisra SK., Hooi LP., Shyan LP., Chieh LB., Candasamy M., Sahu PS. (2019). Effect of geraniol and clarithromycin combination against gastric ulcers induced by acetic acid and Helicobacter pylori in rats. Pharmacognosy Research, 11(4): 356-362

Bodnar RJ. (2011). Epidermal growth factor and epidermal growth factor receptor: The yin and yang in the treatment of cutaneous wounds and cancer. Advanced Wound Care, 2(1):24-29. https://doi.org/10.1089/wound.2011.0326

Bowman K., Leong KW. (2006). Chitosan microparticles for oral drug and gene delivery. International Journal of Micromedicine, 1(2): 117-128

Britton JR., George-Nascimento C., Udall JN., Koidovsky 0. (1989). Minimal hydrolysis of epidermal growth factor by gastric fluid of preterm infants. Gut, 30:327-332. https://doi.org/10.1136/gut.30.3.327

Brown TD., Whitehead KA., Mitragotri S. (2020). Materials for oral delivery of proteins and peptides. Nature Reviews Materials, 5: 127148. https://doi.org/10.1038/s41578-0190156-6

Brownsey GJ., Noel TR., Parker R., Ring SG. (2003). The glass transition behavior of the globular protein bovine serum albumin. Journal of Biophysical, 85:3943-50. https://doi.org/ 10.1016/S0006-3495(03)74808-5.

Deacon MP., Clive JR., Phillip MW., Saul JBT., Martyn CD., SS. (Bob) Davis Stephen EH. (2000). Atomic Force Microscopy of Gastric Mucin and Chitosan Mucoadhesive Systems. Biochemistry Journal, 348: 557-563.
Deng QY., Zhou CR., Luo BH. (2006). Preparation and characterization of chitosan nanoparticles containing lysozyme. Pharmaceutical Biology, 44: 336-342

Dutta SK., Matossian H., Hamburger A., Vaeth J. (1987). Effects of low concentrations of epidermal growth factor and human salive on cellular proliferation of gastric mucosal explants. Gastroenterology, 92: 1378. https://doi.org/10.1136/gut.38.4.629-b

Goodsell DS. (2003). The molecular perspective: epidermal growth factor. Oncologist, 8: 496497.

https://doi.org/10.1634/theoncologist.8-5496

Grenha A., Gomes ME., Rodrigues M., Santo VE., Mano JF., Neves NM., Reis RL. (2009). Development of new chitosan/carrageenan microparticles for drug delivery applications. Journal of Biomedical Material Research, 5(5): 591-595. https://doi:.org/10.1166/jbn.2009.1067

Fitzpatrick SL., LaChance MP., Schultz GS. (1984). Characterization of epidermal growth factor receptor and action on human breast cancer cells in culture. Cancer Research, 44(8): 3442-3447. PMID: 6331647

Hoebler C., Lecannu G., Belleville C., Devaux MF., Popineau Y., Barry JL. (2002). Development of an in vitro system simulating buccogastric digestion to assess the physical and chemical changes of food. International Journal of Food Science and Nutrition, 53: 389-402

Huang JQ., Sridhar S., Hunt RH. (2002). Role of Helicobacter pylori infection and nonsteroidal aniinflammatory drus in peptic ulcer disease: a meta-analysis, Lancet, 359:14-22

Itoh M., Matsuo Y. (1994). Gascric ulcer treatment with intravenous human epidermal growth factor: a double-blind controlled clinical study, Journal of Gastroenterology and Hepatology, 9: Supplement 1:S78-83.

Jachimska B., Wasilewska M., Adamczyk Z. (2008). Characterization of globular protein solutions by dynamic light scattering, electrophoretic mobility, and viscosity measurements. Langmuir, 24:6866-72. doi: 10.1021/la800548p.

Jennings JA. (2017). Controlling chitosan degradation properties in vitro and in vivo in Chitosan Based Biomaterials Volume 1, Eds. Jennings JA., Bumgardner, JD. 159-182. 
Woodhead Publishing Series in Biomaterials: Number 122

Kim K., Wu HG., Jeon SR. (2015). Epidermal growth factor-induced cell death and radiosensitization in epidermal growth factor receptor-overexpressing cancer cell lines. Anticancer Research, 35(1): 245-253.

Konturek JW., Hengst K., Konturek SJ., Domschke W. (1997). Epidermal Growth Factor in Gastric Ulcer Healing by Nocloprost, a Stable Prostaglandin E2 Derivative, Scandinavian Journal of Gastroenterology, 32:10, 980-984. https://doi.org/10.3109/00365529709011 213

Kozlova N., Samylenki A., Drobot L., Kietzmann T, (2016). Urokinase is a negative modulator of Egf-dependent proliferation and motility in the two breast cancer cell lines MCF-7 and MDA-MB-231. Molecular Carcinogensis, 55(2): 170- 181 https://doi.org/10.1002/mc.22267

Kundu P., Das S., Chattopadhyay N. (2019). Managing efficacy and toxicity of drugs: targeted delivery and excretion. International Journal of Pharmaceutics, 565: 378-390

Machida T. (1981). A study of intragastric $\mathrm{pH}$ in patients with peptic ulcer - with special reference to the clinical significance of basal $\mathrm{pH}$ value, Journal of Gastroenterology, 16(5):447-58.

Nurmalasari. (2010). Konstruksi Gen Sintetik EGFsyn PengkodeHuman Epidermal Growth Factor (hEGF) Menggunakan Metode Thermodinamical Balanced Inside-Out (TBIO). Skripsi. Fakultas Matematika dan Ilmu Pengetahuan Alam. Universitas Indonesia. Jakarta.

Ogiso H., Ishitani R., Nureki O., Fukai S., Yamanaka M., Kim JH., Saito K., Sakamoto A., Inoue M., Shirouzu M., Yokoyama S. (2002). Crystal structure of the complex of human epidermal growth factor and receptor extracellular domains panel. Cell, 110:775787.

https://doi.org/10.1016/S00928674(02)00963-7

Pahwa R., Saini N., Kumar V., Kohli K. (2012). Chitosan-based gastroretentive floating drug delivery technology: An updated review, Expert Opinion Drug Delivery, 9(5): 525-539. $10.1517 / 17425247.2012 .673581$
Playford RJ., Marchbank T., Calnan DP, et al. (1995). Epidermal growth factor is digested to smaller, less active forms in acidic gastric juice. Gastroenterology, 108: 92-101. https://doi.org/10.1016/00165085(95)90012-8

Posselt G., Crabtree JE., Wesser S. (2017). Proteolysis in Helicobacter pilori-induced gastric cancer. Toxins (Basel), 9(4): 134. https://doi.org/10.3390/toxins9040134

Raza A., Hayat U., Bilal M., Iqbal HMN., Wang JY. (2020). Zein-based micro- and microconstructs and biologically therapeutic cues with multi-functionalities for oral drug delivery systems. Journal of Drug Delivery Science and Technology, 58, 101818.

Sriwidodo, Subroto T., Maksum IP., Subarnas A., Kesumawardhany B., Lestari DMDD., Umar AK. (2020). Preparation and optimization of chitosan-hEGF micropartice using ionic gelation method stabilized by polyethyene glycol (PEG) for wound healing therapy. International Journal of Pharmceutical Sciences and Research. https://doi.org/ 10.26452/ijrps.v11i1.1962

Suzuki H., Nishizawa T., Tsugawa H., Mogami S., Hibi T. (2012). Roles of oxidative stress in stomach disorders. Journal of Clinical Biochemistry and Nutrition, 50(1): 35-39. https://doi.org/10.3164/jcbn.11-115SR

Syam AF., Sakidin M., Wanandi SI., Rani AA. (2009). Molecular Mechanism of Healing Process of Peptic Ulcer. Acta Medicine of Indonesia, 41(2):95-98

Tarnawaski A., (2000). Molecular mechanism of ulcer healing, Drug News Perspective, 13(3):158-168

Triwulandari E., Fahmiati S., Sampora Y., Meliana Y. (2018). Effect of polyanions variation on the particle size of chitosan nanoparticle prepared by ionic gelation method. AIP Conference Proceedings, 2024(1): 020028. https://doi.org/10.1063/1.5064314

Thorne RG., Hrabetova S., Nicholso C. (2004). Diffusion of epidermal growth factor in rat brain extracellular space measured by integrative optical imaging. Journal of Neurophysioly, 92: 3471

Walker F., Zhang HH., Burgess AW. (2007). Identification of a novel EGF-senstiive cell cylcle checkpoint. Experimental Cell Research, 313: 511-526

Wong WKR., Kwong KWY. (2016). Application of recombinant human epidermal growth 
factor to effective treatment of scalds. Journal of Analytical and Pharmaceutical Research, 3(1): 00045. https://doi.org/ 10.15406/japlr.2016.03.00045

Yang W., Fu J., Wang T., He N. (2009). Chitosan/sodium microparticles: tripolyphosphate characterization and application as drug carrier. Journal of Biomedical Nanotechnology, 5(5): 591-595. https://doi.org/10.1166/jbn.2009.1067

Zeng X and Ruckenstein E. (1998). Cross-linked macroporous chitosan anion-exchange membranes for protein separation. Journal of Membrane Science, 148(2): 195-205.
Zhang P., and Liu C. (2020). Enhancement of skin wound healing by rhEGF-loaded carboxymethyl chitosan microparticles. Polymers, 12(7): 1612. htpps://doi.org/10.3390/polym12071612

Zheng T., Cherubin P., Cilenti L., Teter K., Huo Q. (2016). A simple and fast method to study the hydrodynamic size difference of protein disulfide isomerase in oxidized and reduced form using gold microparticles and dynamic light scattering, Analyst. 141: 934-938. https://doi.org/10.1039/c5an02248g. 